DOI 10.31558/2519-2949.2018.2.19

УДК $327+339$

Конопка Н. О., Костів Б. Б., Національний університет «Острозька академія»

\title{
ПРОБЛЕМИ ЕНЕРГЕТИЧНОЇ ЗАЛЕЖНОСТІ ДЕРЖАВ ЦЕНТРАЛЬНОЇ АМЕРИКИ І КАРИБСЬКОГО БАСЕЙНУ
}

Стаття присвячена аналізу проблеми енергетичної залежності країн Центральної Америки і Карибського басейну. На основі статистичних та аналітичних даних автори роблять спробу виявити особливості й специфіку розвитку енергетичного сектору досліджуваних крайн, проаналізувати позитивні і негативні тенденції та визначити перспективи більшого унезалежнення держав регіону в енергетичному секторі. Особлива увага зосереджена на проблемах енергетичної безпеки та шляхах їх подолання. Також автори розглядають проблему низького рівня доступу жителів більшості досліджуваних країн до електроенергії. У роботі аналізується рівень залежності регіону від імпорту нафти, нафтопродуктів, природного газу та вугілля. Автори простежують головні джерела постачання традичійного викопного палива у держави регіону. Здійснено спробу поділити країни регіону на групи ризику за ступенем залежності від імпорту вуглеводнів. У роботі розглянуто реалізацію спільних проектів щодо підвищення рівня енергетичної незалежності та безпеки у рамках інтеграційних об 'єднань. Зокрема автори дають оцінку проекту інтеграиії електричних мереж країн Центральної Америки та впровадженню Регіонального ринку електроенергї (Mercado Eléctrico Regional), який сприяв зміцненню стабільності електроенергетичної системи регіону. Також увагу приділено спільній політиці держав Карибського басейну у сфері енергетики. Розглядається програма держав Карибського співтовариства (CARICOM) з розвитку відновлюваної енергетики. Автори очінюють ефективність реалізації иієї програми в контексті сьогоднішнього стану енергетичного сектору у країнах Карибського басейну. Крім того, у статті розглянуто діяльність деяких глобальних міжнародних інститучій в енергетичному секторі у краӥнах досліджуваного регіону. Так розглядаються проекти Міжнародної агениї із відновлюваної енергетики (IRENA) та Світового банку.

Ключові слова: Центральна Америка та Карибський басейн, енергетичний сектор, енергетична безпека, традииійні енергоресурси, відновлювальна енергетика, SIEPAC, Mercado Eléctrico Regional, IRENA, Світовий банк.

Постановка проблеми. Енергетична незалежність $є$ одним із ключових елементів енергетичної безпеки як кожної окремої держави, так і регіональних об'єднань. Особливого значення проблеми енергетичної незалежності набувають для країн, які не володіють значними запасами традиційних енергетичних ресурсів (нафта, газ, вугілля, атомна енергетика) або не мають їх зовсім. Саме у такому становищі перебувають більшість держав Центральної Америки і Карибського басейну. Наше дослідження дасть змогу краще зрозуміти, яким чином необхідно організовувати енергетичну безпеку країни в умовах відсутності або недостатності традиційних енергетичних ресурсів.

Мета дослідження. Необхідно зрозуміти чи володіють країни регіону достатньою електроенергетичною потужністю, щоб забезпечувати внутрішні потреби. Також варто проаналізувати структуру енергетичного сектору країн, щоб визначити, наскільки генерація електроенергії залежить від імпорту традиційних джерел. Насамкінець, потрібно оцінити, яким чином держави намагаються подолати проблеми енергетичної залежності, та наскільки успішними $€$ їхні зусилля.

Аналіз останніх досліджень. Дослідженням розвитку енергетичного сектору країн Центральної Америки і Карибського басейну займаються кілька міжнародних неурядових агенції та дослідницьких установ, зокрема Bloomberg New Energy Finance та Міжнародне агентство з відновлюваних джерел енергії (IRENA). Bloomberg публікує щорічні звіти «Climatescope», в яких детально аналізується стан енергетики країн, що розвиваються, та країн із перехідною економікою. Чимало аналітичних матеріалів й даних оприлюднює також IRENA, однак увага у цих публікаціях зосереджена здебільшого на розвитку відновлюваної енергетики, а проблеми енергетичної залежності залишаються мало розкритими. Цікавими $\epsilon$ окремі журналістські дослідження 
The Guardian, зокрема публікація Ліндсей Фендт 2017 р. під назвою «All that glitters is not green: Costa Rica's renewables conceal dependence on oil». Дослідження розглядає проблему залежності Коста-Ріки від імпорту традиційного палива. Окремі статистичні та аналітичні дані розміщені на ресурсах EIA (Міністерства енергетики США), СІА (Центрального розвідувального управління США). Зокрема важливою для нашого дослідження стала інформація про рівень електрифікації у країнах регіону, яка опублікована у звіті CIA «The World Factbook». На сайті ЕIA подано інформацію про обсяги споживання, імпорту, виробництва, видобутку нафти і нафтопродуктів, природного газу, вугілля та електроенергії у країнах світу, зокрема і в досліджуваному регіоні. Заслуговують уваги також «кейс сторіз» (case stories), які з 2010 p. регулярно розміщує на своїх ресурсах Організація економічного співробітництва та розвитку в рамках ініціативи «Aid For Trade». Мета цих публікацій полягає у глибшому аналізі цілей, викликів, результатів та наслідків програми «Aid For Trade». Одну із таких «кейс сторі», яка присвячена реалізації програми SIEPAC, використано у нашому дослідженні. Крім того, Міжамериканський банк розвитку як один із головних фінансових донорів перспективних регіональних проектів теж регулярно публікує інформацію про реалізацію ініціатив у секторі енергетики, зокрема і про проект SIEPAC.

Проте перелічені публікації не розкривають цілісної картини енергетичної залежності регіону. У нашому дослідженні ми спробуємо комплексно та цілісно розглянути означену проблему.

До досліджуваного геополітичного регіону належать Беліз, Гондурас, Гватемала, Коста-Ріка, Нікарагуа, Панама, Сальвадор - континентальні; Американські Віргінські Острови, Антигуа і Барбуда, Аруба, Барбадос, Гаїті, Гренада, Домініка, Домініканська Республіка, Кайманові Острови, Куба, Кюрасао, Монтсеррат, Пуерто-Ріко, Сент-Вінсент і Гренадіни, Сент-Кіттс і Невіс, Сент-Люсія, Тринідад і Тобаго, Ямайка та ін. - острівні. Географічно до регіону належать також Венесуела, Колумбія та Мексика, проте в геополітичному вимірі ці країни суттєво відрізняються від усіх інших у регіоні, тому вони не стали об'єктом дослідження.

В Центральній Америці та Карибському басейні залежність від імпортних енергоресурсів більша, ніж у будь-якій іншій частині Західної півкулі, i, як наслідок, існують найбільші можливості для «нафтової дипломатії», що дозволяє впливати на зовнішню та внутрішню політику держав регіону. Основними експортерами енергоресурсів до досліджуваних країн є США, Мексика, Венесуела, Колумбія, менше Еквадор, Бразилія та держави ОПЕК. Зокрема, США експортують нафту та нафтопродукти до Багамських островів, Колумбії, Кюрасао, Домініканської республіки, Нікарагуа, Панами. Згідно із статистичними даними за 2016-2017 рр. обсяги експорту до Багамських островів, Колумбії, Домініканської республіки суттєво зросли [16]. Американський експорт природнього та скрапленого газу спрямовується до Багамських островів, Барбадосу та Домініканської республіки [15]. Мексика, маючи значні обсяги ресурсів, експортує до Белізу електроенергію та нафту до Домініканської республіки [10]. Венесуела, згідно угоди «Pеtrocaribe» 2005 р. й до сьогодні, не зважаючи на політичну та економічну кризу, постачає за пільговими цінами нафту у держави Центральної Америки та Карибського басейну. До угоди приєдналися фактично всі держави регіону, окрім Барбадосу, Монтсеррат та Тринідад і Тобаго [2]. Окрім того імпортером венесуельської нафти є Куба. Колумбія є нетто-експортером енергетичних ресурсів та експортує значні об'єми нафти-сирцю, нафтопродуктів, газу, вугілля та гідроенергії, що дозволяє ій бути одним із впливових гравців, зокрема в Центральній Америці та Карибському басейні.

Щоб зрозуміти, наскільки розвинутим $є$ енергетичний сектор в регіоні, доцільно буде розділити досліджувані країни на кілька категорій. До першої категорії належать держави, які виробляють достатньо електроенергії для забезпечення своїх власних потреб. Такими є майже усі досліджувані країни регіону [9]. До тих держав, які залежали від імпорту електроенергії належать лише Беліз та Сальвадор [9]. У 2015 р. Беліз імпортував 230 млн. кВт·год електроенергії, при цьому щорічно майже 40\% спожитої в країні електроенергії надходить із сусідньої Мексики [9]. Сальвадор у 2015 р. імпортував 1,066 млн. кВт ·од, а це приблизно 16\% від кількості спожитої енергії [7; 9]. Попри це, у сфері електроенергетики регіон $є$ у значній мірі незалежним.

Проте для кращого розуміння картини варто звернути увагу на обсяги виробництва й споживання електроенергії та проаналізувати інфраструктурний розвиток енергетичного сектору у регіоні, зокрема ступінь електрифікованості.

Станом на 2012-2016 pр. лише дві країни регіону були електрифіковані на 100\% - це Беліз і Багами. Ще чотири держави електрифіковані на рівні від 98 до 99,9\%. До таких належать Домініканська Республіка, Коста-Ріка, Куба та Тринідад і Тобаго [9]. При досягненні рівня електрифікації у 100\% ці країни зможуть виробляти достатньо електроенергії для власних потреб. 
Ситуація в інших країнах дещо гірша. Показники для них такі: Сальвадор - 94\% електрифікації, Ямайка - 93\%, Панама - 91\%, Гондурас - 82\%, Гватемала - 78\%, Нікарагуа - 78\%, Гайті - всього $38 \%$. Для країн, які розташовані на Антильських островах, середній показник електрифікації станом на 2012 р. становив $91 \%$ [9].

Зауважимо, що Сальвадор і зараз імпортує частину електроенергії, щоб покрити рівень домашнього споживання, а при стовідсотковій електрифікації залежність від імпорту зросте. Можна припустити, що Панама і Ямайка при електрифікації на рівні, близькому до $100 \%$, все ще зможуть зберегти самостійність в галузі електроенергетики при збереженні рівня виробництва енергії станом на 2015 р. Країни Антильських островів через своє географічне положення для досягнення максимального рівня електрифікації змушені будуть нарощувати потужність власних електростанцій, а для цього доведеться або розвивати відновлювану енергетику, або ж збільшити обсяги імпорту нафтопродуктів і природного газу, оскільки власного видобутку цих ресурсів країни не ведуть. Гаїті теж доведеться нарощувати потужність виробництва електроенергії, однак у Гаїті $€$ ще один варіант - імпорт безпосередньо електроенергії, а не енергоресурсів, із Домініканської Республіки. Проте, цей варіант зробить країну залежною від одного постачальника. Втім, для Гаїті перспектива стовідсоткової електрифікації $\epsilon$ занадто довгостроковою 3 огляду на рівень економічного розвитку країни - ВВП Гаїті на душу населення у 2016 р. становив лише 739 дол. США [20]. Опція збільшення імпорту електроенергії із сусідніх держав $\epsilon$ можливою $\mathrm{i}$ для континентальних країн регіону, які завдяки географічному розташуванню мають можливість диверсифікувати напрямки постачання електроенергії.

Опираючись на такі критерії як обсяг використання вуглеводнів для виробництва електроенергії, обсяг розвіданих запасів, видобутку та імпорту нафти, природного газу i нафтопродуктів можна поділити країни досліджуваного регіону на три групи ризику.

Перша група - це держави, які не мають власних енергетичних ресурсів у вигляді нафти і природного газу та імпортують лише готові нафтопродукти. До цієї групи належать Американські Віргінські Острови, Антигуа і Барбуда, Аруба, Багами, Гаїті, Гондурас, Гренада, Домініка, Кайманові Острови, Коста-Ріка, Кюрасао, Монтсеррат, Панама, Сальвадор, Сент-Вінсент і Гренадіни, Сент-Кіттс і Невіс та Сент-Люсія [9]. Їх також можна розділити на дві підкатегорії на держави, які для виробництва електроенергії використовують в основному вуглеводні, та на країни, у яких добре розвинутий сектор відновлюваної енергетики. До останніх у цій групі належать лише Гондурас, Домініка, Коста-Ріка, Панама і Сальвадор, лише п’ять держав із сімнадцяти. Всі інші від 80 до 100\% електроенергії отримують шляхом спалювання вуглеводнів. Якщо врахувати, що свого видобутку нафти, природного газу та вугілля вони не ведуть і навіть не мають власних розвіданих запасів цих ресурсів, то стає очевидною залежність від імпорту готових продуктів переробки нафти. Зрозуміло, що країнам простіше купувати нафтопродукти, оскільки не треба витрачати фінансові ресурси на організацію власної переробної галузі. Однак, в регіоні є держави з надзвичайно високим рівнем безробіття. Наприклад, у Гаїті - 40,6\% (дані на 2010 р.), у Гренаді - 33,5\% (дані на 2013 р.), у Домініці - 23\% (дані на 2000 р.), у Сент-Вінсенті $18,8 \%$ (дані на 2008 р.) [9]. Нафтопереробні заводи могли б забезпечити робочі місця для тисяч громадян, а беручи до уваги відносно низьку чисельність населення більшості країн регіону, рівень безробіття б суттєво скоротився. Та з іншого боку, відсутність нафтопереробних заводів означає, що немає і зайвого згубного впливу на довкілля. Попри це, перша виділена нами група є категорією держав, енергетична залежність яких є дуже високою, що знижує рівень національної безпеки.

До другої групи ми віднесли країни, які теж не ведуть видобутку вуглеводнів і не мають власних родовищ, проте імпортують не лише нафтопродукти, а й нафту-сирець i/aбо природний газ. Це чотири країни: Домініканська Республіка, Нікарагуа, Пуерто-Ріко та Ямайка. 3 них лише Нікарагуа активно використовує відновлювані ресурси для виробництва електроенергії, інші більш ніж на $80 \%$ залежні від ТЕС [9]. Енергетичний сектор цих держав є більш диверсифікованим і збалансованим, ніж країн першої групи, а це гарантує вищий ступінь стабільності енергомереж і більшу стійкість енергетичного ринку.

Третя група країн веде власний видобуток енергоносіїв, тому не має надмірної залежності від імпорту. До таких країн належать Барбадос, Беліз, Гватемала, Куба та Тринідад і Тобаго [9]. При цьому вони також імпортують значну частину енергоносіїв, та все ж їхній енергетичний сектор $\epsilon$ значно більш диверсифікованим у порівнянні із країнами перших двох груп. Однак варто окремо відзначити, що Беліз не забезпечує себе електроенергією самостійно, покриваючи більшу частину своїх потреб енергоресурсами з Мексики. 
Варто, звісно, розуміти, що такий поділ держав регіону на групи ризику за енергетичними показниками $є$ у визначеній мірі умовним. Держави часто імпортують значну кількість енергоносіїв чи електроенергії для того, щоб потім продати їх іншим країнам. Та попри це, наведені дані дають можливість окреслити загальну картину енергетичного ринку регіону і виявити основні проблеми.

У регіоні є країни, які окрім нафти, нафтопродуктів і природного газу для виробництва електроенергії використовують також вугілля, хоча жодна із досліджуваних держав не видобуває цей ресурс самостійно. Споживачами вугілля є Гондурас (95 тис. тонн на рік), Гватемала (1,315 тис. тонн), Домініканська Республіка (979 тис. тонн), Коста-Ріка (1 тис. тонн), Панама (387 тис. тонн), Пуерто-Ріко (1,963 тис. тонн), Тринідад і Тобаго (6,4 тис. тонн) та Ямайка (107 тис. тонн) [14]. Це в певній мірі сприятливо впливає на рівень диверсифікованості енергетики перелічених країн, однак підвищує залежність від імпорту енергоресурсів.

Зважаючи на існуючі проблеми в енергетичній сфері, цілком очевидно, що держави регіону намагаються спільно шукати шляхи їх подолання. Так, наприклад, шість держав Центральної Америки (Панама, Коста-Ріка, Гондурас, Нікарагуа, Сальвадор та Гватемала) ініціювали проект об'єднання національних електромереж в єдину інтегровану мережу [12]. Проект SIEPAC (Sistema de Interconexión Eléctrica de los Países de América Central) об’єднав в єдину мережу 15 підстанцій шести центральноамериканських країн: Гватемали, Сальвадору, Гондурасу, Нікарагуа, Коста-Ріки та Панами [19]. Будівництво лінії успішно завершилося у 2013 р. [11] Проект було профінансовано Міжамериканським банком розвитку, урядом Іспанії, Центральноамериканським банком економічної інтеграції та ін.

Того ж року почав діяти Регіональний ринок електроенергії (Mercado Eléctrico Regional (MER)) [11], завдяки чому з 2013 до 2014 рр. вхідна потужність мережі зросла вдвічі - 688 Гвт до 1,445 Гвт [12]. Головним експортером електроенергії у цій мережі є Гватемала, головним споживачем Сальвадор, який, як нам уже відомо, не може самостійно виробляти достатню для внутрішнього споживання кількість енергії. У 2001 р. до проекту долучились також Мексика і Колумбія. Мексикансько-Гватемальська мережа функціонує з 2010 р. При цьому необхідно звернути увагу, що $72 \%$ виробничих потужностей цієї лінії розташовані у Гватемалі [12]. Це запобігає надто сильному зростанню впливу Мексики на країни регіону. Що ж до Панамсько-Колумбійської лінії, то наразі проект іiі побудови знаходиться на стадії громадських обговорень [12]. Якщо проект буде завершено, то MER простягнеться від Мексики до Колумбії через усю Мезоамерику і об'єднає два Американські континенти.

Попри те, що проект неодноразово піддавався критиці, зокрема і через вплив на довкілля, така ініціатива є важливою для регіону, адже слугує першим серйозним кроком у бік спільного подолання енергетичних проблем. На нашу думку, немає підстав побоюватися надмірного посилення впливу якоїсь із країн, наприклад Гватемали як основного експортера електроенергії, адже $з$ огляду на проаналізовані дані бачимо, що майже усі держави Центральної Америки здатні на даному етапі забезпечити свої енергетичні потреби самостійно. Проект лише гарантує стабільність постачання та стійкість ринку електроенергії у кожній 3 країн-учасниць, а також енергетичну незалежність від позарегіональних ринків.

Однак, подібні проекти неможливі для острівних держав Карибського басейну, які через це змушенні шукати інші шляхи підвищення енергетичної автономності, зокрема завдяки розвитку відновлюваної енергетики, залученню інвесторів та реалізації глобальних і регіональних проектів. Окрім того, державам Центральної Америки та Карибського басейну варто змінювати свої підходи до енергетичної політики, зважаючи на нестабільний нафтовий ринок, зумовлений політичними, економічними та екологічними кризами.

Однією з перших країн регіону, яка досягла вагомих успіхів у даній галузі є Коста-Ріка. У 2017 р. ця невелика держава 300 днів отримувала електрику виключно з відновлюваних джерел. За даними, які надав Національний центр Коста-Ріки з контролю енергії, 99,62\% виробництва електроенергії в країні генерується з п'яти відновлюваних джерел. Так, гідроенергетика забезпечує $78,26 \% *$ потреб країни в електроенергії, за нею вітроенергетика $(10,29 \%)$, геотермальна $(10,23 \%)$, сонячна енергія і біопаливо $(0,84 \%)$ та воднева $(0,38 \%)[1 ; 3]$.

Та якщо взяти до уваги весь енергетичний сектор, а не лише електроенергетику, то залежність Коста-Ріки від нафтопродуктів лише зросла. У країні на 1000 жителів припадає 287 автомобілів, що перевищує середньосвітовий показник і середній показник у Латинській Америці. При цьому лише $2 \% 3$ усіх автомобілів є гібридами або електрокарами. У 2016 р. продаж бензину зріс на 11\%. Експерти прогнозують, що споживання вуглеводнів буде і надалі зростати, а отже зростатиме i залежність від їх імпорту [5]. 
Та все ж, у сфері електроенергетики Коста-Ріка може стати прикладом реалізації відновлюваних енергетичних проектів для держав Центральної Америки та Карибського басейну, які прагнуть диверсифікувати джерела енергії та стати енергетично незалежними.

За підтримки регіональних та міжнародних організацій, таких як CARICOM та Світовий банк, країни Карибського басейну розпочали перехід до альтернативних джерел енергії.

У березні 2013 р. країни-члени CARICOM (Гайана, Барбадос, Ямайка, Тринідад і Тобаго, Антигуа і Барбуда, Монтсеррат, Сент-Кіттс і Невіс, Домініка, Гренада, Сент-Люсія, Сент-Вінсент і Гренадіни та Беліз) прийняли програму нової регіональної енергетичної політики, основною метою якої проголошено трансформацію енергетичного сектору й визначення стратегічних цілей розвитку [8]. Серед ключових завдань програми визначено досягнення максимального рівня енергоефективності, енергетичної безпеки та розвиток енергетичного ринку регіону. В доповнення до програми держави-учасниці прийняли порядок денний розвитку відновлюваних джерел енергії. Він передбачає забезпечення $20 \%$ енергетичних потреб кожної із країн, які входять до організації, із відновлюваних джерел до 2017 р. Довгострокова ціль полягає у досягненні рівня 47\% до 2027 р. [8] Якщо державам вдасться реалізувати цю програму, то Карибський регіон стане значно більш енергетично самостійним, адже кожна із держав має вдосталь потенційних відновлюваних ресурсів.

Що ж до реалізації програми, то з наявних на сьогодні даних важко говорити про успішність втілення короткострокової мети. Лише кілька держав можуть похвалитися позитивним результатом. Так Домініка ще у 2015 р. досягла рівня 21,7\% [9]. У Белізі, за даними звіту «Climatescope-2017» у 2016 p. 56\% потужності електроенергетики припадало на відновлювані джерела [7]. Частка відновлюваної енергетики у Гайані та Ямайці станом на 2016 р. становила по 15\%, у Барбадосі $11 \%[13 ; 17 ; 6]$. Згідно 3 інформацією агентства IRENA потужність відновлюваної енергетики Барбадосу і Ямайки у 2017 р. не змінилася, залишившись на рівні 19 і 189 МВт відповідно [18].

Завдяки спільним проектам CARICOM та Світового банку у державах східної частини Карибського басейну, зокрема в Домініці, Гренаді, Монтсерраті, Сент-Люсії, Сент-Кітсі і Невісі, Сент-Вінсенті та Гренадінах реалізовуються проекти щодо впровадження споживання геотермальної енергії; на Ямайці - вітрової енергії, покращується інвестиційний клімат, впроваджується механізм доступності інформації про можливості впровадження того чи іншого енергетичного проекту [21].

Окрім того у 2016 р. Міжнародне агентство з відновлюваної енергетики (IRENA) оголосило про намір вкласти 46 млн дол. США у будівництво об'єктів «зеленої енергетики» замість застарілих дизельних електростанцій в чотирьох країнах - Антигуа і Барбуда, Буркіна-Фасо, Кабо Верде, Сенегал. Найбільші вкладення, 15 млн дол. США, передбачається направити в Антигуа і Барбуда для будівництва вітрових та сонячних енергетичних об’єктів. Згідно з проектом, сукупна потужність споруджуваних станцій складе 4 кВт.год та дозволить зменшити викиди вуглекислого газу в атмосферу. Подібні проекти агентства вже були реалізовані в Аргентині, Еквадорі, Кубі, СентВінсенті та Гренадінах [4].

Отже, більшість досліджуваних країн Центральної Америки і Карибського басейну станом на 2015 рік володіли достатнім потенціалом, щоб забезпечувати власні потреби в електроенергії. Проте значна частина держав все ще залишалися неелектрифікованими на $100 \%$, а тому існує потреба в нарощенні виробництва електроенергії при впровадженні програм з надання усім громадянам доступу до електромережі.

Основна частина держав регіону (17 із 26 досліджуваних) відчувають залежність від імпорту енергоносіїв у вигляді готових нафтопродуктів, при цьому лише п'ять із зазначених держав активно використовують відновлювану енергетику. Найбільшими постачальниками нафти і нафтопродуктів у регіон є США, Мексика, Венесуела та Колумбія. США активно нарощують обсяги експорту нафти та скрапленого газу, що знижує рівень енергетичної автономності регіону. Продовжує постачати нафту і Венесуела, хоча країна уже кілька років перебуває у політичній та економічній кризі, а тому постачання енергоресурсів є під загрозою.

Одним із аспектів проблеми $є$ те, що у регіоні майже немає нафтопереробних заводів, які б моли суттєво знизити рівень безробіття у країнах, де цей показник $є$ критично високим.

Що ж до відновлюваної енергетики, то в регіоні вона представлена здебільшого великими гідроелектростанціями. Однак, вони не можуть виробляти передбачену кількість енергії під час посухи. Тому існує необхідність розвитку нетрадиційної відновлюваної енергетики (альтернативної). 
Держави регіону розуміють, що у сфері енергетики існують проблеми, які роблять їх залежними від зовнішніх акторів. Саме тому держави Мезоамерики ініціювали проект SIEPAC, який передбачає будівництво єдиної центральноамериканської електромережі та створення Регіонального ринку електроенергії. Проект на сьогодні успішно реалізується, що дозволяє країнам-учасницям забезпечувати стабільне постачання енергії та розвивати енергетичний ринок.

Острівні держави Карибського басейну не мають змоги реалізовувати подібні проекти, тому для підвищення рівня енергетичної автономності їм необхідно розвивати відновлювану енергетику. Саме для цього CARICOM прийняла у 2013 р. спільну програму 3 метою підвищення рівня енергетичної безпеки шляхом розвитку відновлюваної енергетики. Однак, лише кілька держав об'єднання змогли досягти короткострокової мети програми, що ставить під сумнів перспективи реалізації прийнятої стратегії.

Відтак, для держав Центральної Америки та Карибського басейну, які є залежними не лише від імпортних енергоресурсів, але й від окремих країн-експортерів, варто розвивати власні енергетичні сектори для більшої енергетичної незалежності. Найбільш перспективними напрямками є співпраця цих країн у рамках інтеграційних об'єднань, що дозволить спільними зусиллями подолати нерівномірність та неструктурованість енергетичного ринку, залучити більшу кількість міжнародних інвестицій, виробити механізми енергетичної безпеки регіону.

\section{Примітка:}

* У 2016 р. в Коста-Ріці ввели в експлуатацію найбільшу ГЕС в Центральні Америці «Ревентазон». Проект було профінансовано за рахунок бюджетних коштів, кредитів Міжамериканського банку розвитку, Центрально-американського банку економічної інтеграції, Європейського інвестиційного банку, Міжнародної фінансової корпорації, Світового банку, місцевих банків.

\section{Бібліографічний список:}

1. Коста-Ріка майже рік провела на відновлюваних джерелах енергії [Електронний ресурс]. - Режим доступу: https://hromadske.ua/posts/kosta-ryka-maizhe-rik-provela-na-vidnovliuvanykh-dzherelakh-enerhii

2. Нищая Венесуэла торгует нефтью в убыток [Електронний ресурс]. - Режим доступу: https://economy.apostrophe.ua/news/vneshnjaja-torgovlja/2016-08-04/nischaya-venesuela-torguet-neftyu-vubyitok/67630

3. Романюк М. Відновлювана енергетика: Коста-Ріка на неї перейшла, а Україна - зможе? / М. Романюк [Електронний ресурс]. - Режим доступу: https://www.ukrinform.ua/rubric-technology/2353631-vidnovluvanaenergetika-kostarika-na-nei-perejsla-a-ukraina-zmoze.html

4. \$46 Million in Loans Announced for Four Renewable Energy Projects in Africa, Caribbean [Електронний pecypc]. - Режим доступу: http://www.irena.org/newsroom/pressreleases/2016/Jan/46-Million-in-Loans-Announcedfor-Four-Renewable-Energy-Projects-in-Africa-Caribbean

5. All that glitters is not green: Costa Rica's renewables conceal dependence on oil [Електронний ресурс]. Режим доступу: https://www.theguardian.com/world/2017/jan/05/costa-rica-renewable-energy-oil-cars

6. Barbados [Електронний ресурс]. - Режим доступу: http://global-climatescope.org/en/country/barbados/\#/ enabling-framework

7. Beliz [Електронний ресурс]. - Режим доступу: http://global-climatescope.org/en/country/belize/\#/enablingframework

8. Caribbean targets 47\% renewables by 2027 [Електронний ресурс] // Jamaica Observer - Режим доступу: http://www.jamaicaobserver.com/business/Caribbean-targets-47--renewables-by-2027_13797684

9. CIA World Factbook [Електронний ресурс]. - Режим доступу: https://www.cia.gov/library/publications/ resources/the-world-factbook.html

10. Dominican Republic Imports from Mexico [Електронний ресурс]. - Режим доступу: https://tradingeconomics.com/dominican-republic/imports/mexico

11. Energy integration in Central America: Full steam ahead [Електронний ресурс]. - Режим доступу: https://www.iadb.org/en/news/webstories/2013-06-25/energy-integration-in-central-america\%2C10494.html

12. Energy Integration: The Central American experience in designing and implementing the Regional Electricity Market [Електронний ресурс]. - Режим доступу: https://www.oecd.org/aidfortrade/casestories/casestories-2017/CS139-SIECA-Integración-Energética-La-experiencia-de-Centroamérica-en-el-diseño-e-implementación-del-MercadoEléctrico-Regional-English-Translation.pdf.

13. Guyana [Електронний ресурс]. - Режим доступу: http://global-climatescope.org/en/country/guyana/\#/ enabling-framework

14. International - U.S. Energy Information Administration [Електронний ресурс]. - Режим доступу: https://www.eia.gov/beta/international/

15. International - U.S. Energy Information Administration. Natural gas [Електронний ресурс]. - Режим 
доступу: https://www.eia.gov/dnav/ng/ng_move_expc_s1_a.htm

16. International - U.S. Energy Information Administration. Petroleum \& other Liquids [Електронний peсурс]. - Режим доступу: https://www.eia.gov/dnav/pet/pet_move_expc_a_EPC0_EEX_mbbl_a.htm.

17. Jamaica [Електронний ресурс]. - Режим доступу: http://global-climatescope.org/en/country/jamaica/\#/ enabling-framework

18. Renewable Capacity Statistics 2018 [Електронний pecypc]. - Режим доступу: http://www.irena.org/ publications/2018/Mar/Renewable-Capacity-Statistics-2018

19. Sistema de Interconexión Eléctrica de los Países de América Central (SIEPAC) [Електронний ресурc]. Режим доступу:

http://www.proyectomesoamerica.org/joomla/index.php?option=com_content\&view=article\&id=171.

20. The World Bank. GDP per сарita [Електронний pecypc]. - Режим доступу: https://data.worldbank.org/ indicator/NY.GDP.PCAP.CD?end=2016\&locations $=$ HT\&start=1991\&view $=$ chart

21. Turning point for energy security in the Caribbean [Електронний ресурс]. - Режим доступу: http://www.worldbank.org/en/news/feature/2016/05/04/turning-point-for-energy-security-caribbean

\section{Konopka N. O., Kostiv B. B. The issues of energy dependence of Central American and Caribbean states}

The article is devoted to the analysis of the energy dependence issue of Central American and Caribbean States. On the basis of statistical and analytical data the authors try to find peculiarities and specific nature of the development of energy sector of the studied countries, to analyze positive and negative trends and to define prospects of making the states more independent in energy sector. Particular attention is paid to the issues of energy security and their solution. The authors also scrutinize the problem of poor access to electricity among the citizens of researched countries. The work analyzes the level of region's dependence on oil, oil products, natural gas and coal import. In addition, the main sources of providing traditional fossil fuels to the countries of the region are identified. There has been an attempt to divide the countries into risk groups according to the level of hydrocarbon import dependence. The article also examines implementing common projects considering the increase of the level of energy independence and safety within integration associations. The authors particularly make evaluation of the project for integrating the electric networks of the Central American States and the implementation of Mercado Electrico Regional, which contributed to strengthening of electric power system stability in the region. Joint policies of the Caribbean States in energy scene are given consideration as well. Furthermore, the Renewable Energy Development Programme of the Caribbean Community (CARICOM) is studied. The authors evaluate the effectiveness of the programme implementation in the context of current status of the energy sector in the Caribbean States. Besides, the article considers the activity of some global international institutions in the energy sector of the researched countries. For instance, the projects of The International Renewable Energy Agency (IRENA) and The World Bank are examined.

Key words: Central America and the Caribbean, energy sector, energy safety, conventional energy, renewable energy, SIEPAC, Mercado Eléctrico Regional, IRENA, The World Bank. 